\title{
Methane production of two roughage and total mixed ration as influenced by cellulase and xylanase enzyme addition
}

\author{
Belete Shenkute Gemeda*, Abubeker Hassen
}

University of Pretoria - Dept. of Animal and Wildlife Sciences, Pretoria 0002 - Hatfield - Pretoria - South Africa.

*Corresponding author <beletegemeda@gmail.com>

Edited by: Concepta Margaret McManus Pimentel

\begin{abstract}
In recent decades supplementation of animal feeds with exogenous fibrolytic enzymes has substantially improved digestibility and animal performance. However, information related to associated methane production is limited and inconsistent. This study evaluated the effect of cellulase and xylanase enzymes on in vitro methane production of Eragrostis curvula hay, maize (Zea mays) stover and a total mixed ration (TMR) at seven levels of the two enzymes. Feed samples were incubated for 2, 12, 24 and $48 \mathrm{~h}$ in an in vitro batch culture with buffer and rumen fluid, and fibrolytic enzymes. Gas production was measured using a pressure transducer connected to a data tracker, while methane gas was analysed using a gas chromatograph which was calibrated with standard $\mathrm{CH}_{4}$ and $\mathrm{CO}_{2}$. Increases in the level of enzyme application resulted in increases in gas volume, total volatile fatty acid (VFA) production, dry matter (DM) disappearance and associated increases in methane production. The linear increase in percentage and volume of methane production in tandem with increases in level of enzyme application might be due to increased fermentation, and organic matter degradability that resulted in a shift in VFA production towards acetate. Considering the efficiency of DM and neutral detergent fiber degradation and production of associated VFA with levels of enzymes, the use of $1 \mathrm{mg} \mathrm{g}^{-1} \mathrm{DM}$ of enzyme can be a good option for the feeds tested. However, they cannot decrease methane production. It will be very important to consider other hydrogen sinks that can capture directly extra $\mathrm{H}^{+}$produced by the addition of enzyme so that their supplementation could be very efficient and environmentally sound.

Keywords: digestibility, fermentation, fibrolyitc enzymes, gas production
\end{abstract}

Received April 23, 2014

Accepted July 27, 2014 improvement in fermentation, digestibility and animal performance (Krueger et al., 2008; Azzaz et al., 2012). Although improvement in digestibility and animal performance due to enzyme supplementations have been reported there is limited information available with regard to associated methane production. In a few studies where methane production was an interest, a number of authors reported either decreased methane production (Eun and Beauchemin, 2007), or increased methane production (Chung et al., 2012) while no effect has also been reported (McGinn et al., 2004). Thus the effects vary with the type of feed, $\mathrm{pH}$, microbial sources and various other factors.

It is also important to consider the level of enzyme supplementation as it determines the levels of digestion in ruminants as well as affecting the profitability and sustainability of enzymes in animal production. This study was undertaken with the specific aim of evaluating the effects of fibrolytic cellulase and xylanase enzymes on in vitro methane production of Eragrostsis curvula hay, maize (Zea mays) stover and a total mixed ration (TMR) at different levels of application.

\section{Materials and Methods}

are characterized in general by less propionate shifted fermentation with more methane production as compared with concentrates. Improving digestibility and reduction of methane are crucial in the utilization of fibrous feeds for sustainable livestock production.

The inclusion of cellulase and xylanase in ruminant feeding has been proven to bring about substantial

\section{Feeds and enzymes}

The cellulase and xylanase enzymes used in the study are concentrated liquids of acid cellulase (E.C. 3.2.1.4) and acid-neutral endo-1, 4- $\beta$-D-xylanase (E.C. $3.2 .1 .8)$, respectively. They are produced by the fermenta- 
tion of non-GMO Trichoderma longibrachiatum (formerly Trichoderma reesei). The endo-glucanase assay from cellulase enzyme using $1 \%(\mathrm{w} / \mathrm{v})$ carboxymethyl cellulose (CMC) under $\mathrm{pH}$ of $4.0,4.8,5.8$, and 6.0 were $4,232.2$, $4,484.3,3,373.6$ and $2,141.9$ reduced sugars per $\mu \mathrm{mol}$ enzyme while the exo-glucanase assay using $1 \%(\mathrm{w} / \mathrm{v})$ cellulose were $3.0,4.3,1.5$ and 1.0 reduced sugars per $\mu \mathrm{mol}$ enzyme, respectively. Xylanase activity using $1 \%$ (w/v) Birchwood xylan at $\mathrm{pH}$ of $4.0,4.8,5.8$, and 6.0 were $1,676.2,2,497.6,1,831.5$ and 1,737.2 reduced sugars per $\mu$ mol enzyme, respectively. In this study each enzyme was studied at seven levels i.e. 0.0, 0.5, 1.0, 2.0, 3.0, 4.0 and $5.0 \mathrm{mg} \mathrm{g}^{-1}$ dry matter (DM) feed for Cellulase $(0.5$ being the level recommended by the manufacturer) and $0.0,0.25,1.0,2.0,3.0$ and $4.0 \mathrm{mg} \mathrm{g}^{-1} \mathrm{DM}$ feed for xylanse ( 0.25 being the recommended level by the manufacturer), respectively. Eragrostis curvula, maize stover and TMR (formulated for adult sheep) were used as test feeds. Their chemical composition is shown in Table 1.

\section{In vitro gas production measurement}

\section{Collection of rumen fluid from donor sheep}

The rumen fluid was collected from two rumen cannulated Merino wethers fed on ad libtum amount of alfalfa (Medicago sativa) hay before the morning feeding. Approximately $500 \mathrm{~mL}$ of the rumen fluid was collected from each donor animal, mixed, strained through four layers of cheesecloth and then transferred to pre-heated thermos flasks. In the laboratory, the flasks were emptied into an industrial blender while being purged with $\mathrm{CO}_{2}$ to maintain anaerobic conditions (Grant and Mertens, 1992). After blending, the rumen fluid was transferred to a large glass beaker that was kept inside a $39{ }^{\circ} \mathrm{C}$ water bath and was continuously purged with $\mathrm{CO}_{2}$ and continuously stirred as recommended by Goering and Soest (1970). Thereafter, the required amount of rumen fluid was added to the buffer solution in the respective incubation vessels in a ratio of one part rumen fluid to four parts of buffer solution. This rumen buffer solution was used for the study.

\section{Reducing buffer solution}

The rumen buffer solution, both micromineral and macromineral solutions, were prepared in large quantities and utilized as needed. The micromineral solution was stored in a dark glass bottle in order to maintain the quality of the solution. Reducing solution contained $4 \mathrm{~g}$ of ammonium bicarbonate $\left(\mathrm{NH}_{4} \mathrm{HCO}_{3}\right)$ and $35 \mathrm{~g}$ of sodium bicarbonate $\left(\mathrm{NaHCO}_{3}\right)$ dissolved in distilled water and brought up to $1 \mathrm{~L}$ in volumetric flask. The macromineral solution contained $5.7 \mathrm{~g}$ of sodium hydrogen phosphate dibasic $\left(\mathrm{Na}_{2} \mathrm{HPO}_{4}\right), 6.0 \mathrm{~g}$ of potassium phosphate monobasic $\left(\mathrm{KH}_{2} \mathrm{PO}_{4}\right)$, and $0.6 \mathrm{~g}$ of magnesium sulfate heptahydrate $\left(\mathrm{MgSO}_{4} \cdot 7 \mathrm{H}_{2} \mathrm{O}\right)$ dissolved in distilled water and brought up to $1 \mathrm{~L}$ in a volumetric flask. The micromineral solution contained $13.2 \mathrm{~g}$ of calcium chloride dihydrate $\left(\mathrm{CaCl}_{2} .2 \mathrm{H}_{2} \mathrm{O}\right), 10.0 \mathrm{~g}$ of manganese chloride tetrahydrate $\left(\mathrm{MnCl}_{2} \cdot 4 \mathrm{H}_{2} \mathrm{O}\right), 1.0 \mathrm{~g}$ of cobalt chloride hexahydrate $\left(\mathrm{CoCl}_{2} \cdot 6 \mathrm{H}_{2} \mathrm{O}\right)$, and $8.0 \mathrm{~g}$ of Ferric chloride, hexahydrate $\left(\mathrm{FeCl}_{2} \cdot 6 \mathrm{H}_{2} \mathrm{O}\right)$ dissolved in distilled water and brought up to $100 \mathrm{~mL}$ in a volumetric flask. A litre of medium contained $2.5 \mathrm{~g}$ of tryptone, $500 \mathrm{~mL}$ of distilled water, $0.125 \mathrm{~mL}$ of micromineral solution, $250 \mathrm{~mL}$ of buffer solution, $250 \mathrm{~mL}$ of macro-mineral solution, $1.25 \mathrm{~mL}$ of $0.1 \%$ resazurin solution, $0.313 \mathrm{~g}$ L-cysteine hydrochloride and $0.313 \mathrm{~g}$ sodium sulphide.

In the morning, before the commencement of the experiment, the appropriate amounts of distilled water, rumen buffer solution, macro and micro mineral solutions were mixed with the tryptose and prepared $0.1 \%(\mathrm{w} / \mathrm{v})$ resazurin. The enzyme solution was prepared based on the required rate(s) for specific experimental treatments in order to deliver the desired amount of enzyme in a $1 \mathrm{~mL}$ aliquot. Appropriate amounts of L-cysteine hydrochloride and sodium sulphide were weighed and directly added to the rest of the solution once all chemicals were dissolved. As soon as the reducing agent was added, the buffer solu-

Table 1 - Mean ( \pm SE) nutrient composition of test feeds.

\begin{tabular}{|c|c|c|c|}
\hline \multirow{2}{*}{ Nutrients composition } & \multicolumn{3}{|c|}{ Test feeds (\%) } \\
\hline & Eragrostis curvula & Maize stover & TMR \\
\hline$\overline{\mathrm{DM}}$ & $94.51 \pm 0.84$ & $92.3 \pm 0.05$ & $93.9 \pm 0.05$ \\
\hline Ash & $3.75 \pm 0.04$ & $2.28 \pm 0.01$ & $7.48 \pm 0.026$ \\
\hline $\mathrm{OM}$ & $90.76 \pm 0.04$ & $90.1 \pm 0.8$ & $86.4 \pm 0.024$ \\
\hline $\mathrm{EE}$ & $1.08 \pm 0.02$ & $0.87 \pm 0.018$ & $5.99 \pm 0.14$ \\
\hline $\mathrm{CP}$ & $3.11 \pm 0.03$ & $2.05 \pm 0.02$ & $19.8 \pm 0.047$ \\
\hline ADF & $50.3 \pm 0.23$ & $52.2 \pm 0.39$ & $20.3 \pm 0.4$ \\
\hline NDF & $84.4 \pm 0.32$ & $81.2 \pm 1.8$ & $29.6 \pm 0.61$ \\
\hline$A D L$ & $7.63 \pm 0.13$ & $10.8 \pm 0.02$ & $3.49 \pm 0.040$ \\
\hline ADIN (\% CP to ADF) & $0.98 \pm 0.03$ & $0.27 \pm 0.01$ & $11.64 \pm 0.4$ \\
\hline NDIN (\% CP to NDF) & $1.42 \pm 0.03$ & $1.04 \pm 0.01$ & $14.8 \pm 0.04$ \\
\hline ME (MJ kg-1 calculated) & $5.9 \pm 0.03$ & $5.94 \pm 0.01$ & $34.7 \pm 0.03$ \\
\hline
\end{tabular}

DM-dry matters; OM-organic matter; EE-ether extract; CP-crude protein; ADF-acid detergent fibre; NDF-neutral detergent fibre; ADL-lignin; ADIN-the nitrogen content of ADF; NDIN-the nitrogen content of NDF; SE-standard error. Composition of total mixed ration (TMR) in percentage. Maize stover or Hominy chop (26.8), Wheat bran (7.9), Eragrostis curvula Hay (14.9), Alfalfa hay (14.9), Sun flower oil meal (21.8), Soya meal (3.96), Molassases (6.94), Limeston (1), Dicalcium phosphate (0.5), Salt (0.5), Sodium bicarbonate (0.5), Premix (0.4). 
tion was placed in a $39{ }^{\circ} \mathrm{C}$ water bath and bubbled with $\mathrm{CO}_{2}$. The serum bottles were then sealed with a rubber stopper and left at $39{ }^{\circ} \mathrm{C}$ until the buffer solution was clear, indicating that the solution was sufficiently reduced.

\section{Measurement of gas production}

A semi-automated system was used to measure in vitro gas production from feed substrate fermented with enzymes at different levels in a $120 \mathrm{~mL}$ serum bottle incubated at $39{ }^{\circ} \mathrm{C}$, as described by Theodorou et al. (1994). The system consists of digital data tracker connected to a pressure transducer with a needle at the tip. About $500 \mathrm{mg}$ of respective feed sample was weighed in the $120 \mathrm{~mL}$ serum bottle, and $1 \mathrm{~mL}$ of the appropriate enzyme treatment was directly pipetted onto the substrate and incubated for $24 \mathrm{~h}$. Then $42 \mathrm{~mL}$ of rumen flu$\mathrm{id}+$ medium were added under a stream of $\mathrm{CO}_{2}$ to each of the serum bottles and closed with rubber stoppers and crimp seal caps. The needle was inserted through a rubber stopper of each serum bottle for about $5 \mathrm{~s}$ to release a small amount of gas that could accumulate so as to create a starting point for the incubation. All serum bottles were returned to the incubator, and the rotary shaker was turned on at $120 \mathrm{rpm}$. Gas pressure was taken at $2,4,8,12,16,24,32$ and $48 \mathrm{~h}$ of incubation. To quantify the gas production derived from the culture medium and the ruminal inoculums, two blanks were included in every batch of analysis. Each treatment was replicated twice per run and a total of four independent runs were executed for every treatment. The pressure and volume values of each reading time were recorded, and added to the values of the previous readings. Thus, the cumulative pressure and volume of the fermentation gases were obtained. Fermentation was terminated after $48 \mathrm{~h}$ by removing the serum bottles from the incubator and placing them on ice. The supernatants were taken immediately, pipetted and stored at $-20^{\circ} \mathrm{C}$ for analysis of ammonia N (McDonald et al., 1960) and VFA (Ottenstein and Bartley, 1971) at a later stage.

\section{In vitro degradability}

To evaluate in vitro DM degradability at $48 \mathrm{~h}$ of fermentation, rumen fluid samples and DM residuals were collected from two bottles per treatment. All the serum bottle contents were transferred into gush crucibles and using a vacuum filter system the fluid was filtered and dried in an oven at $55{ }^{\circ} \mathrm{C}$ for $48 \mathrm{~h}$ after which DM disappearance was determined. The blank corrected sample weight was referred to as apparently undegradable DM, and degradability was calculated as the ratio of degradable DM to that of substrate DM incubated. Total degradable DM was derived from the difference between the weights of DM incubated residues as indicated by formulas described in the manufacturer's manual.

\section{Methane production measurements}

Methane production was measured from the duplicate bottles incubated with each grass sample at 2 ,
12,24 and $48 \mathrm{~h}$. The methane concentration was determined using a gas chromatograph, equipped with a solenoid column packed with silica gel and a Flame Ionization Detector (FID). Gas production from each bottle was recorded and gas samples were immediately taken using a Hamilton syringe. The sampled gas was injected manually (pull and push method of sample injection) into a GC, which was already calibrated with standard $\mathrm{CH}_{4}$ and $\mathrm{CO}_{2}$. Two blanks were included for correcting the $\mathrm{CH}_{4}$ produced from the inoculum in each run and a total of two runs were executed for each sample. The measured methane concentration was related to the respective total gas measurement in order to estimate its concentration (Tavendale et al., 2005), and subsequently converted to energy and mass values using $39.54 \mathrm{~kJ} \mathrm{~L}^{-1}$ $\mathrm{CH}_{4}$ and $0.716 \mathrm{mg} \mathrm{mL}^{-1} \mathrm{CH}_{4}$ factors, respectively (Santoso et al., 2007).

\section{Calculations and statistical analysis}

Metabolizable energy ( $\left.\mathrm{ME}, \mathrm{MJ} \mathrm{kg}^{-1} \mathrm{DM}\right)$ was estimated according to Menke and Steingass (1988) as fol-

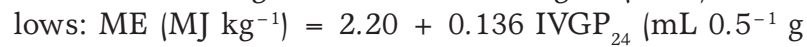
$\mathrm{DM})+0.057 \mathrm{CP}(\% \mathrm{DM})$. Methane production was calculated as follows: $\mathrm{g} \mathrm{CH}_{4} \mathrm{~g}^{-1}$ digested $\mathrm{DM}=$ (gas production $24 \mathrm{~h} \times\left(\left[\mathrm{CH}_{4} 24 \mathrm{~h}\right]\right)$ - gas produced blank $24 \mathrm{~h} \times\left[\mathrm{CH}_{4}\right.$ blank $24 \mathrm{~h}]) / \mathrm{g}^{-1}$ digested DM according to Chaves et al. (2006). The experimental design used in this study was completely randomized. The data were statistically analyzed using the 'GLM' proc of SAS (Statistical Analysis System, Version 9.2) and differences between the means were determined using the Tukey test.

\section{Results}

\section{Addition of Exogenous Fibrolytic Enzymes (EFE) on fermentation of substrates}

The addition of the two enzymes increased the DM degradability of the test feeds $(p<0.05)$, with increasing application levels of enzymes (Table 2). The fermentation of roughage substrates was generally very low for the control treatment (Table 3). However, incubation with the enzymes had improved gas production $(p<0.01)$. Over the $48 \mathrm{~h}$ periods the relative percentage improvement in gas production due to addition of cellulase enzyme ranged between 5 to $53.9,4.5$ to 56.2 and 7.5 to 24.7 (\%) for maize stover, Eragrostis curvula hay and TMR, respectively. The improvement recorded due to addition of xylanase ranged between 3.5 to $62.5,3.2$ to 65.8 and 1.5 to $15.5 \%$ for maize stover, Eragrostis curvula hay and TMR, respectively. High levels of enzyme application resulted in a relatively higher percentage increase in gas production. However, the net improvement associated with an increase in each unit of enzyme added $\left(\mathrm{mg} \mathrm{g}^{-1} \mathrm{DM}\right.$ enzyme) decreased beyond $2 \mathrm{mg} \mathrm{g}^{-1} \mathrm{DM}$ dose for cellulase and $1 \mathrm{mg} \mathrm{g}^{-1} \mathrm{DM}$ for xylanase.

There was a proportional increase in percentage of total VFA as levels of enzyme addition increased (Table 4). The percentage increment in acetate showed a vari- 
Table 2 - Dry Matter (DM) degradation (\%) due to addition of cellulase and xylanase to maize stover (MS), Eragrostis curvula hay (EC) and total mixed ration (TMR) at different levels.

\begin{tabular}{|c|c|c|c|c|}
\hline \multirow{2}{*}{ Enzyme } & \multirow{2}{*}{ Level } & \multicolumn{3}{|c|}{ Test feeds } \\
\hline & & MS & EC & TMR \\
\hline & $\mathrm{mg} \mathrm{g}^{-1} \mathrm{DM}$ & & & \\
\hline \multirow{7}{*}{ Cellulase } & 0 & $54.9 \pm 0.35^{\dagger}$ & $42.9 \pm 0.04^{\dagger}$ & $72.8 \pm 0.34^{f}$ \\
\hline & 0.5 & $55.0 \pm 0.38^{f}$ & $44.4 \pm 0.53^{f}$ & $73.01 \pm 0.71^{f}$ \\
\hline & 1 & $60.3 \pm 0.14^{\mathrm{e}}$ & $46.7 \pm 0.89 e$ & $77.2 \pm 0.08$ \\
\hline & 2 & $66.2 \pm 0.05^{d}$ & $51.1 \pm 0.81^{\mathrm{d}}$ & $81.3 \pm 0.34^{d}$ \\
\hline & 3 & $70.5 \pm 0.11^{c}$ & $57.6 \pm 0.91^{c}$ & $85.2 \pm 0.02^{c}$ \\
\hline & 4 & $75.7 \pm 0.43^{b}$ & $59.8 \pm 0.04^{b}$ & $91.2 \pm 0.12^{b}$ \\
\hline & 5 & $77.8 \pm 0.18^{a}$ & $62.3 \pm 0.29 a$ & $95.1 \pm 0.08^{a}$ \\
\hline \multirow{7}{*}{ Xylanase } & 0 & $54.9 \pm 0.35^{f}$ & $42.9 \pm 0.4 f$ & $72.0 \pm 0.34^{f}$ \\
\hline & 0.25 & $55.2 \pm 0.39^{f}$ & $43.0 \pm 0.5^{e f}$ & $72.0 \pm 0.03^{f}$ \\
\hline & 0.5 & $60.3 \pm 0.06^{e}$ & $45.1 \pm 0.1^{\mathrm{e}}$ & $76.5 \pm 0.17^{\mathrm{e}}$ \\
\hline & 1 & $65.1 \pm 0.06^{d}$ & $48.9 \pm 0.9^{d}$ & $80.8 \pm 0.11^{\mathrm{d}}$ \\
\hline & 2 & $71.0 \pm 0.09 c$ & $51.1 \pm 0.8^{c}$ & $85.2 \pm 0.02^{c}$ \\
\hline & 3 & $75.8 \pm 0.04^{b}$ & $56.5 \pm 1.8^{\mathrm{b}}$ & $89.0 \pm 1.67^{\mathrm{b}}$ \\
\hline & 4 & $79.0 \pm 0.38^{a}$ & $59.8 \pm 0.9^{a}$ & $95.8 \pm 0.08^{a}$ \\
\hline
\end{tabular}

Means with different superscript (letters) across the column for each parameter are different $(p<0.05)$.

Table 3 - Gas production (mL $500 \mathrm{mg}^{-1}$ DM) due to addition of cellulase and xylanase to maize stover (MS), Eragrostis curvula hay (EC) and total mixed ration (TMR) at different levels.

\begin{tabular}{|c|c|c|c|c|c|c|c|c|c|c|}
\hline \multirow{2}{*}{ Enzymes } & \multirow{2}{*}{ Level } & \multicolumn{3}{|c|}{ MS } & \multicolumn{3}{|c|}{$\mathrm{EC}$} & \multicolumn{3}{|c|}{ TMR } \\
\hline & & 12 & 24 & 48 & 12 & 24 & 48 & 12 & 24 & 48 \\
\hline & $\mathrm{mg} \mathrm{g}^{-1} \mathrm{DM}$ & & & & & & & & & \\
\hline \multirow[t]{7}{*}{ Cellulase } & 0 & $4.60^{c}$ & $8.50^{e}$ & $24.4^{\dagger}$ & $2.69^{\dagger}$ & $6.48^{g}$ & $21.7^{\mathrm{g}}$ & $25.9^{\dagger}$ & $44.9^{g}$ & $56.0 \mathrm{~g}$ \\
\hline & 0.5 & $5.20^{c}$ & $9.10^{\text {ed }}$ & $25.0^{f}$ & $3.50^{\mathrm{e}}$ & $7.39^{f}$ & $23.1^{\dagger}$ & $27.1^{\mathrm{e}}$ & $45.9^{\dagger}$ & $58.1^{f}$ \\
\hline & 1 & $5.58^{c}$ & $9.96^{d}$ & $27.1^{\mathrm{e}}$ & $4.60^{d}$ & $9.30^{\mathrm{e}}$ & $27.0^{\mathrm{e}}$ & $28.3^{d}$ & $48.0^{\mathrm{e}}$ & $63.0^{\mathrm{e}}$ \\
\hline & 2 & $7.18^{b}$ & $13.65^{c}$ & $33.0^{\mathrm{d}}$ & $5.80^{c}$ & $9.82^{d}$ & $32.0^{\mathrm{d}}$ & $29.2^{c}$ & $49.3^{d}$ & $66.0^{d}$ \\
\hline & 3 & $8.88^{a}$ & $12.7^{\mathrm{bc}}$ & $38.1^{\mathrm{c}}$ & $6.00^{c}$ & $11.5^{c}$ & $33.1^{\mathrm{c}}$ & $29.8^{c}$ & $50.9^{c}$ & $68.0^{\circ}$ \\
\hline & 4 & $9.90^{\mathrm{a}}$ & $14.8^{\mathrm{a}}$ & $41.0^{\mathrm{b}}$ & $6.80^{\mathrm{b}}$ & $12.2^{\mathrm{b}}$ & $36.0^{\mathrm{b}}$ & $31.5^{\mathrm{b}}$ & $53.0^{\mathrm{b}}$ & $74.0^{\mathrm{b}}$ \\
\hline & 5 & $9.95^{\mathrm{a}}$ & $15.8^{\mathrm{a}}$ & $42.0^{\mathrm{a}}$ & $8.37^{\mathrm{a}}$ & $15.0^{\mathrm{a}}$ & $40.9^{a}$ & $33.8^{\mathrm{a}}$ & $56.0^{\mathrm{a}}$ & $78.0^{\mathrm{a}}$ \\
\hline \multirow[t]{7}{*}{ Xylanase } & 0 & $4.60^{\mathrm{e}}$ & $8.50^{\text {de }}$ & $24.4^{\dagger}$ & $2.69^{f}$ & $6.48^{e}$ & $21.7^{\dagger}$ & $25.9^{e}$ & $44.9^{f}$ & $56.0^{f}$ \\
\hline & 0.25 & $5.51^{d}$ & $8.49^{d e}$ & $24.5^{\dagger}$ & $3.58^{\mathrm{e}}$ & $6.60^{e}$ & $21.8^{\mathrm{f}}$ & $26.0^{e}$ & $50.0^{f}$ & $56.2^{f}$ \\
\hline & 0.5 & $5.30^{\text {de }}$ & $8.35^{\mathrm{e}}$ & $24.6^{\dagger}$ & $3.60^{\mathrm{e}}$ & $6.64^{\mathrm{e}}$ & $23.1^{\mathrm{e}}$ & $27.1^{\mathrm{d}}$ & $45.4^{\mathrm{e}}$ & $58.9^{\mathrm{e}}$ \\
\hline & 1 & $5.31^{\mathrm{ed}}$ & $9.10^{d}$ & $27.5^{\mathrm{e}}$ & $4.39^{d}$ & $8.18^{d}$ & $26.0^{d}$ & $28.7^{c}$ & $48.0^{\mathrm{d}}$ & $63.1^{\mathrm{d}}$ \\
\hline & 2 & $6.60^{c}$ & $11.0^{c}$ & $31.0^{\mathrm{d}}$ & $5.60^{c}$ & $10.0^{c}$ & $30.0^{c}$ & $28.9^{c}$ & $49.0^{c}$ & $65.0^{c}$ \\
\hline & 3 & $7.80^{\mathrm{b}}$ & $13.1^{\mathrm{b}}$ & $34.5^{\mathrm{b}}$ & $6.80^{\mathrm{b}}$ & $12.0^{\mathrm{b}}$ & $33.8^{\mathrm{b}}$ & $30.6^{\mathrm{b}}$ & $51.1^{\mathrm{b}}$ & $70.0^{\mathrm{b}}$ \\
\hline & 4 & $10.2^{\mathrm{a}}$ & $19.8^{\mathrm{a}}$ & $47.8^{\mathrm{a}}$ & $9.98^{\mathrm{a}}$ & $18.9^{\mathrm{a}}$ & $50.1^{\mathrm{a}}$ & $31.7^{\mathrm{a}}$ & $53.0^{\mathrm{a}}$ & $74.1^{\mathrm{a}}$ \\
\hline
\end{tabular}

Means with different superscript (letters) across the column for each parameter are different $(p<0.05)$.

able pattern for the two roughages with increasing levels of enzymes while linear and quadratic patterns were observed for TMR. Propionate production decreased for TMR with increased levels of enzymes while no clear pattern was observed for roughage substrates. The percentage increase in acetate and propionate production for Eragrostis curvula hay test feed was dose dependent. Both acetate and propionate production increased as levels of enzyme application increased for Eragrostis curvula hay. However, for the maize stover test diet, the relative change in acetate and propionate production associated with increasing levels of enzyme application was not consistent. In contrast, for the TMR test diet acetate production appeared to have moderately increased as the levels of enzyme increased, but the propionate production was relatively reduced due to application of enzymes in a dose dependent pattern.

\section{Addition of EFE on methane production}

Increased volume of methane gas was recorded with increased levels of enzyme application for the feeds treated with enzymes, compared to the control samples (Table 5). The addition of enzymes increased $(p<0.01)$ the cumulative volume of methane gas $\left(\mathrm{mL} \mathrm{g} \mathrm{DM}^{-1}\right)$ recorded at various time intervals. The cumulative volume of methane gas increased $(p<0.05)$ as levels of enzyme application increased. However, TMR produced, relatively, the lowest methane volume during all incubation 
Table 4 - Relative percentage increases in total volatile fatty acid (TVFA), acetate $\left(\mathrm{C}_{2}\right)$ and propionate $\left(\mathrm{C}_{3}\right)$ production as a result of the addition of cellulase and xylanase to maize stover (MS), Eragrostis curvula hay (EC) and total mixed ration (TMR).

\begin{tabular}{|c|c|c|c|c|c|c|c|c|c|c|}
\hline \multirow{2}{*}{ Enzyme } & \multirow{2}{*}{ Level } & \multicolumn{3}{|c|}{ MS } & \multicolumn{3}{|c|}{ EC } & \multicolumn{3}{|c|}{ TMR } \\
\hline & & TVFA & $\mathrm{C}_{2}$ & $\mathrm{C}_{3}$ & TVFA & $\mathrm{C}_{2}$ & $\mathrm{C}_{3}$ & TVFA & $\mathrm{C}_{2}$ & $\mathrm{C}_{3}$ \\
\hline \multirow{7}{*}{ Cellulase } & $\mathrm{mg} \mathrm{g}^{-1} \mathrm{DM}$ & & & & & & & & & \\
\hline & 0 & 0.0 & 0.0 & 0.0 & 0.0 & 0.0 & 0.0 & 0.0 & 0.0 & 0.0 \\
\hline & 0.5 & 4.3 & 4.7 & 0.85 & 0.4 & 0.2 & 0.5 & 13.2 & 22.8 & -36.8 \\
\hline & 1 & 24.3 & 22.1 & 25.8 & 30.2 & 45.3 & 28.0 & 13.4 & 23.0 & -33.1 \\
\hline & 2 & 26.3 & 30.3 & 8.12 & 31.3 & 48.2 & 29.2 & 17.0 & 26.9 & -10.5 \\
\hline & 3 & 27.1 & 33.9 & 2.26 & 37.1 & 61.7 & 29.9 & 19.0 & 28.7 & -5.2 \\
\hline & 4 & 27.8 & 26.4 & 28.5 & 39.3 & 67.4 & 30.9 & 19.6 & 28.2 & -25.6 \\
\hline \multirow{6}{*}{ Xylanase } & 0 & 0.0 & 0.0 & 0.0 & 0.0 & 0.0 & 0.0 & 0.0 & 0.0 & 0.0 \\
\hline & 0.25 & 18.2 & 26.8 & -13.5 & 21.3 & 27.7 & 20.4 & 4.96 & 14.6 & -51.0 \\
\hline & 0.5 & 18.8 & 14.7 & 22.4 & 33.4 & 51.6 & 31.2 & 7.15 & 16.8 & -45.8 \\
\hline & 1 & 19.2 & 16.6 & 20.7 & 34.3 & 54.5 & 27.0 & 8.27 & 17.7 & -40.6 \\
\hline & 2 & 19.7 & 28.5 & -17.1 & 39.4 & 63.9 & 34.6 & 15.1 & 24.8 & -12.3 \\
\hline & 3 & 20.9 & 30.4 & -20.0 & 40.7 & 70.4 & 32.5 & 21.9 & 31.3 & -0.8 \\
\hline
\end{tabular}

Table 5 - Volume ( $\mathrm{mL} \mathrm{g} \mathrm{DM}^{-1}$ ) of methane produced due to the addition of different levels of cellulase and xylanase to maize stover (MS), Eragrostis curvula hay (EC) and total mixed ration (TMR) feeds.

\begin{tabular}{|c|c|c|c|c|c|c|c|c|c|c|c|c|c|}
\hline \multirow{2}{*}{ Enzyme } & \multirow{2}{*}{ Level } & \multicolumn{4}{|c|}{ TMR } & \multicolumn{4}{|c|}{ MS } & \multicolumn{4}{|c|}{ EC } \\
\hline & & 2 & 12 & 24 & 48 & 2 & 12 & 24 & 48 & 2 & 12 & 24 & 48 \\
\hline & $\mathrm{mg} \mathrm{g}^{-1} \mathrm{DM}$ & & & & & & & & & & & & \\
\hline & 0 & $0.03^{d}$ & $0.36^{\mathrm{g}}$ & $2.36^{\mathrm{g}}$ & $4.56^{\mathrm{g}}$ & $0.05^{g}$ & $0.85^{f}$ & $4.94 \mathrm{~g}$ & $9.02^{\mathrm{g}}$ & $0.06^{e}$ & $1.83^{d}$ & $4.15^{\mathrm{g}}$ & $9.14^{\mathrm{g}}$ \\
\hline & 0.5 & $0.03^{d}$ & $0.49^{f}$ & $2.64^{\dagger}$ & $5.32^{f}$ & $0.063^{f}$ & $1.04^{\mathrm{e}}$ & $5.26^{\dagger}$ & $9.45^{\dagger}$ & $0.06^{e}$ & $1.75^{\mathrm{e}}$ & $4.39^{f}$ & $9.53^{\dagger}$ \\
\hline & 1 & $0.04^{c}$ & $0.62^{\mathrm{e}}$ & $2.99^{\mathrm{e}}$ & $6.14^{\mathrm{e}}$ & $0.073^{e}$ & $1.13^{\mathrm{d}}$ & $6.06^{e}$ & $11.6^{\mathrm{e}}$ & $0.08^{d}$ & $1.93^{\mathrm{c}}$ & $5.01^{\mathrm{e}}$ & $10.4^{\mathrm{e}}$ \\
\hline \multirow[t]{7}{*}{ Cellulase } & 2 & $0.04^{c}$ & $0.76^{d}$ & $3.26^{d}$ & $6.87^{d}$ & $0.077^{d}$ & $1.49^{c}$ & $7.01^{\mathrm{d}}$ & $14.1^{\mathrm{d}}$ & $0.12^{\mathrm{c}}$ & $2.10^{\mathrm{b}}$ & $5.54^{d}$ & $11.2^{\mathrm{d}}$ \\
\hline & 3 & $0.05^{b}$ & $0.89^{c}$ & $3.55^{c}$ & $7.78^{c}$ & $0.08^{c}$ & $1.89^{\mathrm{b}}$ & $8.20^{\circ}$ & $16.9^{c}$ & $0.12^{c}$ & $2.10^{\mathrm{b}}$ & $6.14^{c}$ & $12.1^{\mathrm{c}}$ \\
\hline & 4 & $0.05^{b}$ & $1.02^{b}$ & $3.88^{b}$ & $8.85^{b}$ & $0.082^{b}$ & $2.16^{a}$ & $9.26^{b}$ & $19.3^{b}$ & $0.13^{b}$ & $2.22^{\mathrm{a}}$ & $6.76^{b}$ & $12.9^{b}$ \\
\hline & 5 & $0.06^{a}$ & $1.16^{\mathrm{a}}$ & $4.28^{a}$ & $10.2^{\mathrm{a}}$ & $0.108^{a}$ & $2.16^{a}$ & $9.85^{a}$ & $20.9^{a}$ & $0.14^{a}$ & $2.23^{a}$ & $7.45^{\mathrm{a}}$ & $13.9^{a}$ \\
\hline & 0 & $0.03^{c}$ & $0.36^{b c}$ & $2.36^{g}$ & $4.56^{g}$ & $0.05^{\mathrm{g}}$ & $0.85^{\mathrm{g}}$ & $4.94^{\dagger}$ & $9.02^{\mathrm{g}}$ & $0.06^{\mathrm{e}}$ & $1.83^{\mathrm{d}}$ & $4.15^{f}$ & $9.14^{\mathrm{g}}$ \\
\hline & 0.25 & $0.03^{c}$ & $0.32^{\mathrm{e}}$ & $2.43^{f}$ & $5.07^{\dagger}$ & $0.08^{e}$ & $1.10^{f}$ & $5.37^{e}$ & $9.29^{t}$ & $0.07^{d}$ & $1.84^{\mathrm{d}}$ & $4.06^{\mathrm{g}}$ & $9.02^{f}$ \\
\hline & 0.5 & $0.03^{c}$ & $0.34^{\text {cd }}$ & $2.46^{\mathrm{e}}$ & $5.71^{\mathrm{e}}$ & $0.06^{f}$ & $1.03^{\mathrm{e}}$ & $5.37^{e}$ & $9.45^{\mathrm{e}}$ & $0.07^{d}$ & $1.89^{c}$ & $4.72^{\mathrm{e}}$ & $9.96^{e}$ \\
\hline \multirow[t]{4}{*}{ Xylanase } & 1 & $0.04^{b}$ & $0.35^{\mathrm{bcd}}$ & $2.57^{d}$ & $6.44^{d}$ & $0.17^{b}$ & $1.12 \mathrm{~d}$ & $5.59^{d}$ & $10.2^{\mathrm{d}}$ & $0.11^{c}$ & $1.98^{b}$ & $5.18^{d}$ & $10.7^{d}$ \\
\hline & 2 & $0.04^{b}$ & $0.36^{\mathrm{bc}}$ & $2.61^{\mathrm{c}}$ & $7.10^{c}$ & $0.11^{d}$ & $1.29^{c}$ & $5.92^{c}$ & $11.2^{\mathrm{c}}$ & $0.11^{c}$ & $1.62^{\dagger}$ & $5.45^{c}$ & $11.1^{c}$ \\
\hline & 3 & $0.05^{a}$ & $0.37^{\mathrm{ab}}$ & $2.71^{\mathrm{b}}$ & $8.06^{b}$ & $0.16^{c}$ & $1.51^{\mathrm{b}}$ & $6.32^{b}$ & $12.3^{b}$ & $0.16^{b}$ & $1.71^{\mathrm{e}}$ & $6.04^{b}$ & $11.9^{b}$ \\
\hline & 4 & $0.05^{a}$ & $0.39^{a}$ & $2.78^{a}$ & $8.90^{\mathrm{a}}$ & $0.28^{a}$ & $2.12^{\mathrm{a}}$ & $7.25^{\mathrm{a}}$ & $15.8^{a}$ & $0.21^{\mathrm{a}}$ & $2.23^{a}$ & $7.19^{\mathrm{a}}$ & $13.6^{a}$ \\
\hline
\end{tabular}

Means with different superscript (letters) across the column for each parameter are different $(p<0.001)$.

periods when compared to methane production from the two roughages tested.

Methane production expressed in mass (methane production $\mathrm{g} \mathrm{DDM}^{-1}$ and $\left.\mathrm{g} \mathrm{NDF}^{-1}\right)$ varied $(p<0.05)$ according to the level of enzyme application (Tables 6 , 7 and 8). Lower values of these parameters $(p<0.05)$ were recorded for the lower levels while higher values were recorded at higher levels of enzyme application. Methane expressed in mass increased with increasing levels of enzymes with linear and quadratic responses. A similar trend was observed for the ratio of methane to digestible $\mathrm{NDF}\left(\mathrm{CH}_{4}\right.$ : $\left.\mathrm{g} \mathrm{NDF}^{-1}\right)$ and the ratio of methane production to $\mathrm{GP}_{24}$ which increased with increases in the level of enzymes for maize stover and TMR. For Eragrostsis curvula hay, however, a lower ratio of methane to total gas production was obtained at the highest levels of enzyme addition.
Methane production had negative correlation with crude protein $(-0.96)$, ash $\left(-0.63^{*}\right)$, ether extract $\left(-0.75^{*}\right)$, non-fibre carbohydrate $\left(-0.88^{*}\right)$, the nitrogen content of neutral detergent fibre $(-0.94 *)$, and the nitrogen content of the acid detergent fibre $\left(-0.77^{*}\right)$ of the test feeds (Table 9). Significant positive correlation was noted between methane production and neutral detergent fibre $\left(0.93^{*}\right)$, acid detergent fibre $(0.96 *)$, Lignin $(0.99 *)$, and cellulose (0.94*).

\section{Discussion}

Relative improvement of in vitro gas production and fibre degradation

The observed substantial improvement in fermentation due to the addition of enzymes as indicated by the relative improvement in percentage of gas pro- 
Table 6 - Effect of cellulase and xylanase addition on methane production expressed in mass, and ratio of methane to fermentation parameters from the total mixed ration (TMR) after $24 \mathrm{~h}$ of incubation.

\begin{tabular}{|c|c|c|c|c|c|c|c|}
\hline Enzyme & Level & $\mathrm{g} \mathrm{kg}^{-1} \mathrm{DDM}$ & $\mathrm{g} \mathrm{kg}^{-1} \mathrm{NDF}$ & $\mathrm{CH}_{4}: \mathrm{ME}$ & $\mathrm{CH}_{4}$ :gas prod & $\mathrm{CH}_{4}: \mathrm{NDF}$ deg & $\mathrm{CH}_{4}:$ TVFA \\
\hline & $\mathrm{mg} \mathrm{g}^{-1} \mathrm{DM}$ & & & & & & \\
\hline & 0 & $1.69^{f}$ & $2.84^{\dagger}$ & $0.068^{\mathrm{g}}$ & $0.053^{\mathrm{g}}$ & $0.83^{f}$ & 0.0306 \\
\hline & 0.5 & $1.89^{\mathrm{f}}$ & $3.14^{\mathrm{e}}$ & $0.076^{\dagger}$ & $0.058^{f}$ & $0.84^{\dagger}$ & 0.0320 \\
\hline & 1 & $2.14^{\mathrm{e}}$ & $3.42^{\mathrm{d}}$ & $0.085^{e}$ & $0.062 \mathrm{e}$ & $0.88^{e}$ & 0.0337 \\
\hline \multirow[t]{7}{*}{ Cellulase } & 2 & $2.33^{d}$ & $3.58^{c}$ & $0.092^{\mathrm{d}}$ & $0.066^{d}$ & $0.91^{\mathrm{d}}$ & 0.0366 \\
\hline & 3 & $2.54^{c}$ & $3.73^{b}$ & $0.100^{c}$ & $0.070^{c}$ & $0.95^{c}$ & 0.0382 \\
\hline & 4 & $2.78^{b}$ & $3.68^{\mathrm{bc}}$ & $0.109^{b}$ & $0.073^{b}$ & $1.05^{\mathrm{b}}$ & 0.0407 \\
\hline & 5 & $3.07^{\mathrm{a}}$ & $4.03^{a}$ & $0.119^{a}$ & $0.076^{a}$ & $1.06^{\mathrm{a}}$ & 0.0447 \\
\hline & 0 & $1.69 \mathrm{~g}$ & $2.84^{\mathrm{g}}$ & $0.068^{g}$ & $0.053^{g}$ & $0.83^{\dagger}$ & 0.0306 \\
\hline & 0.25 & $1.74^{\dagger}$ & $2.92^{\dagger}$ & $0.070^{f}$ & $0.054^{\dagger}$ & $0.83^{\dagger}$ & 0.0307 \\
\hline & 0.5 & $1.91^{\mathrm{e}}$ & $3.19^{e}$ & $0.077^{e}$ & $0.058^{e}$ & $0.84^{\mathrm{e}}$ & 0.0329 \\
\hline \multirow[t]{4}{*}{ Xylanase } & 1 & $2.08^{\mathrm{d}}$ & $3.30^{\mathrm{d}}$ & $0.083^{d}$ & $0.060^{d}$ & $0.88^{d}$ & 0.0349 \\
\hline & 2 & $2.22^{c}$ & $3.37^{c}$ & $0.088^{c}$ & $0.063^{c}$ & $0.92^{c}$ & 0.0369 \\
\hline & 3 & $2.52^{\mathrm{b}}$ & $3.66^{a}$ & $0.099^{b}$ & $0.068^{b}$ & $0.96^{b}$ & 0.0387 \\
\hline & 4 & $2.66^{\mathrm{a}}$ & $3.54^{\mathrm{b}}$ & $0.104^{a}$ & $0.070^{\mathrm{a}}$ & $1.05^{\mathrm{a}}$ & 0.0377 \\
\hline
\end{tabular}

Means with different superscript (letters) across the column for each parameter are different $(p<0.001)$. DDM-digestible dry matter; NDF-neutral detergent fibre; ME-metabolizabe energy; TVFA-total volatile fatty acid.

Table 7 - Effect of cellulase and xylanase addition on methane production, methane expressed in mass and the ratio of methane to fermentation parameters from maize stover after $24 \mathrm{~h}$ of incubation.

\begin{tabular}{|c|c|c|c|c|c|c|c|}
\hline Enzyme & Level & $\mathrm{g} \mathrm{kg}^{-1} \mathrm{DDM}$ & $\mathrm{g} \mathrm{kg}^{-1} \mathrm{NDF}$ & CH4:ME & $\mathrm{CH}_{4}$ :gas prod & $\mathrm{CH}_{4}: \mathrm{NDF}$ deg & CH4:TVFA \\
\hline & $\mathrm{mg} \mathrm{g}^{-1} \mathrm{DM}$ & & & & & & \\
\hline & 0 & $3.54^{\dagger}$ & $8.97^{d}$ & 0.83 & $0.58^{b}$ & $0.55^{g}$ & 0.086 \\
\hline & 0.5 & $3.76^{f}$ & $9.41^{d}$ & 0.86 & $0.58^{b}$ & $0.56^{f}$ & 0.087 \\
\hline & 1 & $4.34^{\mathrm{e}}$ & $10.6^{c}$ & 0.95 & $0.61^{\mathrm{ab}}$ & $0.57^{\mathrm{e}}$ & 0.079 \\
\hline \multirow[t]{7}{*}{ Cellulase } & 2 & $5.02^{\mathrm{d}}$ & $11.2^{\mathrm{bc}}$ & 0.94 & $0.51^{c}$ & $0.62^{\mathrm{d}}$ & 0.090 \\
\hline & 3 & $5.87^{c}$ & $11.9^{a b}$ & 1.08 & $0.64^{a}$ & $0.69^{c}$ & 0.104 \\
\hline & 4 & $6.63^{b}$ & $12.3^{\mathrm{a}}$ & 1.19 & $0.63^{a}$ & $0.75^{b}$ & 0.116 \\
\hline & 5 & $7.05^{\mathrm{a}}$ & $12.6^{\mathrm{a}}$ & 1.20 & $0.62^{\mathrm{ab}}$ & $0.78^{a}$ & 0.118 \\
\hline & 0 & $3.54^{f}$ & $8.97 \mathrm{e}$ & 0.83 & $0.58^{d}$ & $0.55^{f}$ & 0.086 \\
\hline & 0.25 & $3.85^{\mathrm{e}}$ & $9.75^{\mathrm{a}}$ & 0.90 & $0.63^{b}$ & $0.55 f$ & 0.082 \\
\hline & 0.5 & $3.84^{\mathrm{e}}$ & $9.51^{c}$ & 0.88 & $0.65^{\mathrm{a}}$ & $0.56^{\mathrm{e}}$ & 0.079 \\
\hline \multirow[t]{4}{*}{ Xylanase } & 1 & $4.01^{\mathrm{d}}$ & $9.67^{b}$ & 0.89 & $0.61^{c}$ & $0.58^{d}$ & 0.083 \\
\hline & 2 & $4.24^{c}$ & $9.27^{d}$ & 0.87 & $0.52^{\mathrm{e}}$ & $0.64^{c}$ & 0.088 \\
\hline & 3 & $4.53^{b}$ & $9.22^{\mathrm{d}}$ & 0.86 & $0.48^{f}$ & $0.69^{b}$ & 0.099 \\
\hline & 4 & $5.19^{\mathrm{a}}$ & $9.28^{d}$ & 0.78 & $0.37^{\mathrm{g}}$ & $0.78^{a}$ & 0.093 \\
\hline
\end{tabular}

Means with different superscript (letters) across the column for each parameter are different $(p<0.001)$. DDM-digestible dry matter; NDF-neutral detergent fibre; ME-metabolizabe energy; TFVA-total volatile fatty acid.

duction was associated with a simultaneous increase in fiber degradation and VFA production. The observed increase in fermentation and fiber degradability in our study is in agreement with many authors (Elwakeel et al., 2007; Eun and Beauchemin, 2007; Giraldo et al., 2008) who have reported an increase in fiber degradability of diets or feedstuffs with enzyme supplementation. Although the mechanism of this improvement is not clearly known, improvement in the attachment of microorganisms to the plant cell (Wang et al., 2001), or an alteration in the fiber structure due to the effects of the enzyme (Giraldo et al., 2008), or a combination of both, that would have shortened the lag time could be possible reasons for the improvement observed.
When enzymes act on the structures of plant cell walls, the microbes have better access to potentially ferment the fiber (Elwakeel et al., 2007). In addition, the 24 $\mathrm{h}$ pre -incubation of feed sample with enzymes in our study might have enhanced the attachment of enzymes to the cell wall component and thus improved fermentation of the feeds. The positive effect of pre-feeding treatment has been elaborated earlier by many researchers due to the enzyme-substrate pre-incubation interaction (Elwakeel et al., 2007; Krueger and Adesogan, 2008; Alvarez et al., 2009). According to Kung et al. (2002), the formation of stable enzyme-feed complex might increase the resistance of the enzymes to proteolysis and lengthen their residence during later fermentation periods. As a result of a continuous effect of the enzymes on 
Table 8 - Effect of cellulase and xylanase addition on production of methane expressed in mass, and the ratio of methane to fermentation parameters from Eragrostis curvula hay after $24 \mathrm{~h}$ of incubation.

\begin{tabular}{|c|c|c|c|c|c|c|c|}
\hline Enzyme & Level & $\mathrm{g} \mathrm{kg}^{-1} \mathrm{DM}$ deg & $\mathrm{g} \mathrm{kg}^{-1} \mathrm{NDF}$ & $\mathrm{CH}_{4}: \mathrm{ME}$ & $\mathrm{CH}_{4}$ :gas prod & $\mathrm{CH}_{4}: \mathrm{NDF}$ deg & $\mathrm{CH}_{4}:$ TVFA \\
\hline & $\mathrm{mg} \mathrm{g}^{-1} \mathrm{D}$ & & & & & & \\
\hline & 0 & $2.97^{\mathrm{g}}$ & $8.98^{c}$ & $0.70^{b}$ & $0.29^{a}$ & $0.46^{g}$ & 0.117 \\
\hline & 0.5 & $3.14^{f}$ & $9.38^{d}$ & $0.71^{\mathrm{b}}$ & $0.27^{\mathrm{b}}$ & $0.47^{\dagger}$ & 0.126 \\
\hline & 1 & $3.51^{\mathrm{e}}$ & $9.96^{b}$ & $0.74^{b}$ & $0.24^{c}$ & $0.49^{e}$ & 0.125 \\
\hline \multirow[t]{7}{*}{ Cellulase } & 2 & $3.99^{d}$ & $10.04^{b}$ & $0.72^{b}$ & $0.20^{e}$ & $0.55^{d}$ & 0.111 \\
\hline & 3 & $4.50^{c}$ & $10.1^{\mathrm{b}}$ & $0.89^{a}$ & $0.28^{a}$ & $0.63^{c}$ & 0.121 \\
\hline & 4 & $4.84^{b}$ & $10.3^{b}$ & $0.91^{\mathrm{a}}$ & $0.27^{\mathrm{b}}$ & $0.66^{b}$ & 0.122 \\
\hline & 5 & $5.33^{\mathrm{a}}$ & $10.9^{\mathrm{a}}$ & $0.88^{\mathrm{a}}$ & $0.23^{\mathrm{d}}$ & $0.68^{a}$ & 0.130 \\
\hline & 0 & $2.91^{\dagger}$ & $8.78^{d}$ & $0.68^{d}$ & $0.28^{b}$ & $0.46^{\mathrm{e}}$ & 0.117 \\
\hline & 0.25 & $2.97^{\dagger}$ & $8.98^{d}$ & $0.70^{d}$ & $0.29^{\mathrm{b}}$ & $0.46^{e}$ & 0.107 \\
\hline & 0.5 & $3.38^{\mathrm{e}}$ & $10.3^{\mathrm{b}}$ & $0.79^{a b}$ & $0.32^{\mathrm{a}}$ & $0.46^{e}$ & 0.099 \\
\hline \multirow[t]{4}{*}{ Xylanase } & 1 & $3.71^{\mathrm{d}}$ & $10.7^{a}$ & $0.80^{a}$ & $0.28^{b}$ & $0.49^{d}$ & 0.103 \\
\hline & 2 & $3.90^{c}$ & $9.47^{c}$ & $0.77^{\mathrm{bc}}$ & $0.24^{c}$ & $0.58^{c}$ & 0.105 \\
\hline & 3 & $4.32^{b}$ & $8.05^{\mathrm{e}}$ & $0.78^{a b}$ & $0.22^{\mathrm{d}}$ & $0.75^{\mathrm{a}}$ & 0.123 \\
\hline & 4 & $5.15^{\mathrm{a}}$ & $10.5^{\mathrm{ab}}$ & $0.74^{c}$ & $0.17^{e}$ & $0.68^{b}$ & 0.117 \\
\hline
\end{tabular}

Means with different superscript (letters) across the column for each parameter are different ( $p<0.001)$. DM- dry matter; NDF-neutral detergent fibre; ME-metabolizabe energy; TFVA-total volatile fatty acid.

Table 9 - Pearson correlation between in vitro methane production and chemical constituents of test feeds.

\begin{tabular}{lccccc}
\hline Major feed components & $\mathrm{CH}_{4}$ & Fiber components & $\mathrm{CH}_{4}$ & Nitrogen component & $\mathrm{CH}_{4}$ \\
\hline Ash & $-0.63^{*}$ & $\mathrm{NDF}$ & $0.93^{*}$ & $\mathrm{CP}$ & $-0.96^{*}$ \\
EE & $-0.76^{*}$ & $\mathrm{ADF}$ & $0.96^{*}$ & NDIN & $-0.94^{*}$ \\
& & $\mathrm{ADL}$ & $0.99^{*}$ & ADIN & $-0.77^{*}$ \\
& & $\mathrm{NFC}$ & $-0.88^{*}$ & & \\
\end{tabular}

${ }^{*}$ significance difference $(p<0.001)$. EE-ether extract; CP-crude protein; ADF-acid detergent fibre; NDF-neutral detergent fibre; ADL-lignin; ADIN-the nitrogen content of ADF; NDIN-the nitrogen content of NDF; NFC- the non-fibre carbohydrate.

the degradation of fiber of incubated feeds there will be improvement in fermentable metabolizable energy and this, in turn, is expected to increase the flow of microbial- $\mathrm{N}$ and microbial colonization of the substrate, resulting in enhanced fermentation and fiber degradation.

Change in methane production associated with level of enzyme application

The observed linear increase in the volume of methane production with the increase in level of enzyme application might be explained partly by an observed increase in degradability of OM associated with higher VFA production, but shifted towards more acetate production. The observed increase in acetate or acetate:propionate formation shifted VFA fermentation will support this. The increase in acetate or acetate:propionate formation with an increase in the level of enzyme application might have resulted in the formation of more $\mathrm{H}_{2}$ which could be utilized by methanogens to produce methane. In contrast to our finding a decrease in the acetate:propionate ratio in the rumen fluid was reported by Arriola et al. (2011) during an in vivo study. However, the shift in the pattern of VFA seems to be influenced by the type of diet and enzyme preparations (Wang et al., 2001; Giraldo et al., 2008).
Our finding agrees with a number of researchers who found increased VFA production (Arriola et al., 2011) and production of acetate (Giraldo et al., 2007; Gado et al., 2009); which in turn was associated with an increase in methane production attributable to fibrolytic enzyme and their mixtures (Geraldo et al., 2007). Moreover, our finding agrees with Geraldo et al. (2007) who reported an increase in VFA production and production of acetate which in turn was associated with increased methane production as a result of the application of exogenous fibrolytic enzymes and their mixtures. Similar to our study, Chung et al. (2012) reported that increasing the dosage of enzyme supplementation linearly increased enteric $\mathrm{CH}_{4}$ production of dairy cows when compared with the control. On the other hand, McGinn et al. (2004) found no effect of the enzyme on fiber digestibility and methane production in steers fed barley silage based diet whereas Beauchemin et al. (1999) and Yang et al. (1999) reported no effect of fibrolytic enzymes on rumen fermentation. The reported variations in different researches might be due to the type of microbial sources for enzymes and their preparations, the types of substrates evaluated and their methods of application.

Generally, a higher volume of methane was produced relatively from hay and maize stover substrate 
as compared to TMR (comparison not indicated). This might be due to the associated high levels of cell wall components (ADF, NDF, hemicellulose and cellulose) and lower $\mathrm{CP}$ and $\mathrm{ME}$ in the roughage substrate. In this study methane production was positively correlated with the former parameters while it was negatively correlated with the latter parameters (Table 7). This is mainly because the fermentability of the feed to its end products is primarily determined by digestibility that mainly depends on its composition. For example, VFA concentration and its relative proportion that mainly influence methane production are influenced by the nature and fermentation of carbohydrate.

According to Eun et al. (2004), methane production in the rumen generally depends on various factors, mainly the amount of fermentable carbohydrate and levels of fiber in the diet. However, the variation in amount of methane production with enzyme application might be influenced by the type and sources of enzymes, diet under consideration, $\mathrm{pH}$ considered, and rumen microbial population. This is because the feeds fermented with enzyme determine the amount and proportion of VFAs produced that further governs the fermentation pattern and methane production. Therefore, it is very important to consider the ratio of methane to OM degradability and fiber fermented or digested to compare the effects of different enzymes and their levels of application in reducing or increasing methane production.

The increase in methane production with enzyme addition might also be related to the change in rumen microbial and methanogen population as addition of exogenous fibrolytic enzymes may cause a shift in the type of VFA production, specifically, an increase in acetate proportion. Unfortunately, the rumen microbial population change was not assessed in this study but other studies have shown an increase or a shift in the methanogen population (Zhou et al., 2011), increased number of cellulolytic bacteria (Wang et al., 2001; Giraldo et al., 2007; Giraldo et al., 2008) for ruminants supplemented with exogenous fibrolytic enzyme. Although supplementation of exogenous fibrolytic enzyme is reported to cause a shift in the molar proportion of VFA, the shifts in pattern of VFA seem to be influenced by the type of diet and enzyme preparations (Wang et al., 2001; Giraldo et al., 2008) suggesting the need to include additive diets that may play a complementary role by serving as a hydrogen sink.

The enzymes studied were good candidates for the improvement of feed digestibility in ruminant diets, however, they cannot be used as a strategy to decrease methane production because VFA was not propionate shifted. If they have to be used considering efficiency of DM and NDF degradation and cost, the use of $1 \mathrm{mg} \mathrm{g}^{-1}$ DM of enzyme can be a good option with these feeds. It is very important to consider other hydrogen sinks or additives that have some complementary role to directly capture the produced $\mathrm{H}^{+}$, so that addition of enzymes could be very efficient and environmentally sound. In addition, in vivo methane production and the dynamics of rumen microbes and methanogens with exogenous fibrolytic enzyme application need to be considered in future investigations.

\section{Conclusion}

The addition of fibrolytic enzymes increased methane production. The increase was mainly due to a shift in VFA profiles, which favoured acetate. Considering the efficiency of DM and NDF degradation and the production of associated VFA with levels of enzymes, the use of $1 \mathrm{mg} \mathrm{g}^{-1} \mathrm{DM}$ of enzyme can be a good option for the feeds studied. However, they cannot decrease methane production since their increased fermentation result in increased $\mathrm{H}^{+}$due to acetate shifted fermentation.

\section{Acknowledgement}

The project was financed partly by IAEA through a grant received by the University of Pretoria as part of research contract No. SAF 16326. Additional funding was provided by European Community's Framework Programme (FP7/2007-2013) under the grant agreement no 266018 ANIMALCHANGE and the National Research Foundation, South Africa. The authors are also grateful to the University of Pretoria for bursary award.

\section{References}

Alvarez, G.; Pinos-Rodriguez, J.M.; Herrera J.G.; Garcia, J.C.; Gonzalez, S.S.; Barcena, R. 2009. Effects of exogenous fibrolytic enzymes on ruminal digestibility in steers fed high fibre rations. Livestock Science 121: 150-154.

Arriola, K.G.; Kim, S.C.; Staples, C.R.; Adesogan, A.T. 2011. Effect of fibrolytic enzyme application to low- and high- concentrate diets on the performance of lactating dairy cattle. Journal of Dairy Science 94: 832-841.

Azzaz, H.H.; Kholif, A.M.; Murad, H.A.; Hanfy, M.A.; Abdel Gawad, M.H. 2012. Utilization of celluloytic enzymes to improve the nutritive value of banana waste and performance of lactating goats. Journal of Animal Veterinary Advances 7: 664-673.

Chaves A.V.; Thompson, L.C.; Iwaasa, A.D.; Scott, S.L.; Olson, M.E.; Benchaar, C.; Veira, D.M.; McAllister, T.A. 2006. Effect of pasture type (alfalfa Vs grass) on methane and carbon dioxide production by yearling beef heifers. Canadian Journal of Animal Science 86: 409-418.

Chung, Y.H.; Zhou, M.; Holtshausen, L.; Alexander, T.W.; McAllister, T.A.; Guan, L.L.; Oba, M.; Beauchemin, K.A. 2012. A fibrolytic enzyme additive for lactating Holstein cow diets: ruminal fermentation, rumen microbial populations, and enteric methane emissions. Journal of Dairy Science 95: 1419-1427.

Elwakeel, E.A.; Titgemeyer, E.C.; Johnson, B.J.; Armendariz, C.K.; Shirley, J.E. 2007. Fibrolytic enzymes to increase the nutritive value of dairy feedstuffs. Journal of Dairy Science 90: 5226-5236. 
Eun, J.S.; Beauchemin, K.A. 2007. Assessment of the efficacy of varying experimental exogenous fibrolytic enzymes using in vitro fermentation characteristics. Animal and Feed Science Technology 132: 298-315.

Eun, J.S.; Fellner, V.; Gumpertz, M.L. 2004. Methane production by mixed ruminal cultures incubated in dual-flow fermenters. Journal of Dairy Science 87: 112-121.

Gado, H.M.; Salem, A.Z.M.; Robinson, P.H.; Hassan, M. 2009. Influence of exogenous enzymes on nutrient digestibility, extent of ruminal fermentation as well as milk production and composition in dairy cows. Animal and Feed Science Technology 154: 36-46.

Giraldo, L.A.; Tejido, M.L.; Ranilla, M.J.; Carro, M.D. 2007. Influence of exogenous fibrolytic enzymes and fumarate on methane production, microbial growth and fermentation in Rusitec fermenters. British Journal of Nutrition 98: 753-761.

Giraldo, L.A.; Tejido, M.L.; Ranilla, M.J.; Ramos, S.; Carro, M.D. 2008. Influence of direct-fed fibrolytic enzymes on diet digestibility and ruminal activity in sheep fed a grass hay-based diet. Journal of Animal Science 86: 1617-1623.

Grant R.J.; Mertens, D.R. 1992. Impact of in vitro fermentation techniques upon kinetics of fiber digestion. Journal of Dairy Science 75: 1263-1272.

Goering, H.K.; Soest, P.J. van. 1970. Forage Fiber Analyses. (Apparatus, Reagents, Procedures, and some Applications). USDA/ARS, Washington, DC, USA. (Agricultural Handbook, 379).

Krueger, N.A.; Adesogan, A.T.; Staples, C.R.; Krueger, W.K.; Kim, S.C.; Littell, R.C.; Sollenberger, L.E. 2008. Effect of method of applying fibrolytic enzymes or ammonia to Bermudagrass hay on feed intake, digestion and growth of beef steers. Journal of Animal Science 86: 882-889.

Krueger, N.A.; Adesogan, A.T. 2008. Effects of different mixtures of fibrolytic enzymes on digestion and fermentation of bahiagrass hay. Animal Feed Science and Technology 145: 8494.

Kung L.; Cohen, M.A.; Rode, L.M.; Teacher, R.J. 2002. The effect of fibrolytic enzymes sprayed on to forages fed in total mixed ration to lactating dairy cows. Journal of Dairy Science 85: 2396-2402.

McDonald, P.; Stirling, A.C.; Henderson, A.R.; Dewar, W.A.; Stark, G.H.; Davie, W.G.; Macpherson, H.T.; Reid, A.M.; Salter, J. 1960. Studies on Ensilage. Edinburgh School of Agriculture, Edinburgh, Scotland. (Technical Bulletin, 24).
McGinn, S.M.; Beacuchemin, K.A.; Coates, T.; Colombatto, D. 2004. Methane emissions from beef cattle: effects of monensin, sunflower oil, enzymes, yeast, and fumaric acid. Journal of Animal Science 82: 3346-3356.

Menke, K.H.; Steingass, H. 1988. Estimation of the energetic feed value obtained from chemical analysis and in vitro gas production using rumen fluid. Animal Research and Development 28: 7-55.

Ottenstein, D.M.; Bartley, D.A. 1971. Separation of free acids $\mathrm{C}_{2}$ $\mathrm{C}_{5}$ in diluted aqueous solution column technology. Journal of Chromatography Science 9: 673-681.

Santoso, B.; Mwenya, B.; Sar, C.; Takahashi J. 2007. Methane production and energy partition in sheep fed timothy hay silage- or hay-based diets. Journal of Animal Science and Veterinary 12: 27-33.

Tavendale, M.H.; Meagher, L.P.; Pacheco, D.; Walker, N.; Attwood, G.T.; Sivakumaran, S. 2005. Methane production from in vitro rumen incubations with Lotus pedunculatus and Medicago sativa, and effects of extractable condensed tannin fractions on methanogenesis. Animal Feed Science Technology 123-124: 403-419.

Theodorou M.K.; Williams, B.A.; Dhanoa, M.S.; McAllen, A.B.; France, J. 1994. A simple gas production method using pressure transducers to determine the fermentation kinetics of ruminant feed. Animal Feed Science Technology 48: 185-197.

Wang, Y.; McAllister, T.A.; Rode, L.M.; Beauchemin, K.A.; Morgavi, D.P.; Nsereko, V.L.; Iwaasa, A.D.; Yang, W. 2001. Effects of an exogenous enzyme preparation on microbial protein synthesis, enzyme activity and attachment to feed in the rumen simulation technique (Rusitec). British Journal of Nutrition 85: 325-332.

Yang, W.Z.; Beauchemin, K.A.; Rode, L.M. 1999. Effects of an enzyme feed additive on extent of digestion and milk production of lactating dairy cows. Journal of Dairy Science 82: 391-403.

Zhou, M.; Chung,Y.H.; Beauchemin, K.A.; Holtshausen, L.; Oba, M.; McAllister, T.A.; Guan; L.L. 2011. Relationship between rumen methanogens and methane production in dairy cows fed diets supplemented with a feed enzyme additive. Journal of Applied Microbiology 111: 1148-1158. 